\title{
BMJ Open Knee arthroscopy versus conservative management in patients with degenerative knee disease: a systematic review
}

\author{
Romina Brignardello-Petersen, ${ }^{1,2}$ Gordon H Guyatt, ${ }^{1}$ Rachelle Buchbinder,, ${ }^{3,4}$ \\ Rudolf W Poolman, ${ }^{5}$ Stefan Schandelmaier, ${ }^{1,5,6}$ Yaping Chang, ${ }^{1}$ \\ Behnam Sadeghirad, ${ }^{1,7}$ Nathan Evaniew, ${ }^{8}$ Per O Vandvik ${ }^{9,10}$
}

To cite: BrignardelloPetersen R, Guyatt GH, Buchbinder $\mathrm{R}$, et al. Knee arthroscopy versus conservative management in patients with degenerative knee disease:

a systematic review. BMJ Open 2017;7:e016114. doi:10.1136/bmjopen-2017016114

- Prepublication history and additional material is available. To view please visit the journal (http://dx.doi.org/ 10.1136/bmjopen-2017016114).

Received 25 January 2017 Revised 7 February 2017 Accepted 10 February 2017

\section{SLinked}

- http://dx.doi.org/10.1136/ bmjopen-2016-015587

CrossMark

For numbered affiliations see end of article.

Correspondence to Romina BrignardelloPetersen;

brignarr@mcmaster.ca

\section{ABSTRACT}

Objective: To determine the effects and complications of arthroscopic surgery compared with conservative management strategies in patients with degenerative knee disease.

Design: Systematic review.

Main outcome measures: Pain, function, adverse events.

Data sources: MEDLINE, EMBASE, the Cochrane Central Register of Controlled Trials (CENTRAL), Google Scholar and Open Grey up to August 2016.

Eligibility criteria: For effects, randomised clinical trials (RCTs) comparing arthroscopic surgery with a conservative management strategy (including sham surgery) in patients with degenerative knee disease. For complications, RCTs and observational studies.

Review methods: Two reviewers independently extracted data and assessed risk of bias for patientimportant outcomes. A parallel guideline committee (BMJ Rapid Recommendations) provided input on the design and interpretation of the systematic review, including selection of patient-important outcomes. We used the GRADE approach to rate the certainty (quality) of the evidence.

Results: We included 13 RCTs and 12 observational studies. With respect to pain, the review identified high-certainty evidence that knee arthroscopy results in a very small reduction in pain up to 3 months (mean difference $=5.4$ on a 100 -point scale, $95 \% \mathrm{Cl}$ 2.0 to 8.8 ) and very small or no pain reduction up to 2 years (mean difference $=3.1,95 \% \mathrm{Cl}-0.2$ to 6.4 ) when compared with conservative management. With respect to function, the review identified moderate-certainty evidence that knee arthroscopy results in a very small improvement in the short term (mean difference $=4.9$ on a 100 -point scale, $95 \% \mathrm{Cl} 1.5$ to 8.4 ) and very small or no improved function up to 2 years (mean difference $=3.2,95 \%$ $\mathrm{Cl}-0.5$ to 6.8 ). Alternative presentations of magnitude of effect, and associated sensitivity analyses, were consistent with the findings of the primary analysis. Low-quality evidence suggested a very low probability of serious complications after knee arthroscopy.

\section{Strengths and limitations of this study}

- This in an update of previously published systematic reviews on the topic.

- This review is linked to a BMJ Rapid Recommendations project. We conducted the review directed by a guideline panel that included patient representatives. This guideline panel provided detailed input with regards to the patients, interventions and outcomes and the interpretation of the results from this review.

- We included seven new studies, analysed data focusing on clinical interpretability and explicitly assessed the certainty in the estimates of effect.

- We performed meta-analyses using different measures of effect, and conducted subgroup and sensitivity analyses that strengthened our conclusions.

Conclusions: Over the long term, patients who undergo knee arthroscopy versus those who receive conservative management strategies do not have important benefits in pain or function.

Trial registration number: PROSPERO CRD42016046242.

\section{INTRODUCTION}

As a result of degenerative knee disease (osteoarthritis in the knee which can involve the joint lining and/or menisci), $\sim 25 \%$ of people over 45 years, experience pain and other symptoms that may be severe and negatively impact quality of life (QoL). ${ }^{1-3}$ Total knee arthroplasty is the only definitive therapy available, but is reserved for patients with severe disease who fail conservative management.

In the USA, arthroscopic knee surgery in people with degenerative knee disease is the most common ambulatory orthopaedic 
procedure, and the ninth most commonly performed ambulatory procedure overall. ${ }^{4}$ Such surgery results in transient increase in pain and the necessity for restriction in activities for a period of 2-12 weeks. ${ }^{5}{ }^{6}$ Current guidelines recommend against arthroscopic lavage and/or debridement for patients with symptomatic knee osteoarthritis, but do not make specific recommendations for or against partial meniscectomy in those with degenerative meniscal tears (with or without other concomitant degenerative changes). ${ }^{7} 8$ Further, many orthopaedic surgeons suggest that patients with mechanical symptoms and meniscal tears-typically locking or catching of the knee-may benefit from arthroscopic partial meniscectomy. ${ }^{9} 10$

Our systematic review informs the second BMJ Rapid Recommendations, ${ }^{11}$ a new BMJ series of trustworthy clinical practice recommendations published in response to potentially practice-changing evidence. ${ }^{12} \mathrm{~A}$ trial that compared the outcomes of exercise therapy versus knee arthroscopic partial meniscectomy in 140 middle-aged patients with degenerative meniscal tears, published in July 2016 triggered this systematic review. ${ }^{13}$ Previous systematic reviews addressing the impact of arthroscopic knee surgery did not consider all patientimportant outcomes; did not consider patient importance when addressing patient-reported outcomes such as pain, function and QoL; and did not include all currently available randomised clinical trials (RCTs). ${ }^{14} 15$

To determine the effects and complications in patients with symptomatic degenerative knee disease, we performed a systematic review and meta-analysis of arthroscopic surgery with debridement, and/or partial meniscectomy compared with conservative management strategies.

\section{METHODS}

Readers can access the protocol of this systematic review in International prospective registry of systematic reviews (PROSPERO) (CRD42016046242). According to the BMJ Rapid Recommendations process, ${ }^{12}$ a guideline panel provided critical oversight to the review and identified populations, subgroups and outcomes of interest. The panel included eight content experts and front-line clinicians (three orthopaedic surgeons, one rheumatologist, one epidemiologist, one general practitioner and two physiotherapists), four methodologists (three of them whom are also front-line clinicians and general internists) and three patients with lived experience of degenerative knee disease.

All patients received personal training and support to optimise contributions throughout the guideline development process. The patient panel members led the interpretation of the results based on what they expected the typical patient values and preferences to be, as well as the variation between patients. We also considered patients' values and preferences by using the minimally important difference (MID) to interpret the results obtained in the meta-analyses. These MIDs were obtained from a systematic review of studies in which patients were directly asked about the magnitude of change they had experienced, and whether that change was trivial, small but important, or larger. ${ }^{16}$ Clinical experts who were part of the team of that systematic review judged the applicability of such studies to the target population and raised no concerns.

\section{Eligibility criteria}

For the effects of arthroscopic surgery, we included RCTs comparing arthroscopic surgery, including any or all of debridement and/or partial meniscectomy to any conservative management strategy (exercise therapy, injections, drugs, sham surgery) in patients with symptomatic degenerative knee disease (defined as persistent knee pain that affects the patient's QoL and does not respond to conservative treatment), with or without osteoarthritis, of any age. We excluded studies that enrolled patients with acute trauma and those that enrolled fewer than 10 patients. For the complications of arthroscopic surgery, we also included observational studies (OS) (cohort studies, registry studies and case series) in patients with degenerative knee disease undergoing arthroscopic surgery, with or without a comparison group. We excluded studies published before the year 2000 when considering complications (but not effects).

\section{Literature search}

We performed an update of a previously published systematic review ${ }^{15}$ including MEDLINE (PubMed), EMBASE (Ovid) and Cochrane Central Register of Controlled Trials (CENTRAL) (see online supplementary appendix 1) from 1 January 2014 to 16 August 2016. In addition, we constructed specific search strategies for these three databases for one outcome not studied in the previous review (nerve damage), with no date limits. We also searched for grey literature using the first 500 hits from Google Scholar and Open Grey. We did not limit any of the searches by language of publication.

\section{Study selection and data abstraction}

Teams of two reviewers, working independently, performed all study selection and data abstraction using standardised forms and reviewed the titles and abstract of all the references resulting from the searches. We retrieved and reviewed the full text of all references identified as potentially eligible by at least one reviewer. We also reviewed the full text of all references excluded at the full text screening stage in the prior review. ${ }^{17} \mathrm{We}$ included all studies judged as eligible by the two reviewers. Reviewers resolved disagreements by discussion.

Reviewers abstracted characteristics of eligible studies including study design, number of patients enrolled, age and sex distribution, number of patients followed-up, whether partial meniscectomy was performed, 
cointerventions, and outcomes, including pain, function, QoL and knee replacement. When authors reported results from more than one measure of pain or function, we decided a priori to use only the measure ranked highest in a hierarchy of patient-reported outcomes specific to the patients of interest. ${ }^{18}$ When studies had more than two arms, we only used the data from the arms relevant to this study. The review addressed these outcomes at 3 months or less, and at the longest follow-up reported.

The review addressed complication outcomes of mortality, venous thromboembolism (VTE), infection and nerve damage. Reviewers abstracted the absolute number of patients who experienced the outcomes over the follow-up period. When studies did not report VTE but reported pulmonary embolism and deep-vein thrombosis separately instead, we used these numbers to estimate the number of VTEs, considering the potential overlap due to patients experiencing both. ${ }^{19}$ We examined these outcomes over the 3 months following surgery.

\section{Summary measures and data synthesis}

We summarised continuous outcomes (pain, function and QoL) at the study level using the difference in change from baseline between groups. When baseline mean and SD per group at baseline and follow-up, but not change measures, were available, we assumed a within group correlation of 0.5 to estimate the SD of the change from baseline per study arm. If arm-level data were not reported, we abstracted the difference in change from baseline between the groups. When SDs at follow-up were not reported, we assumed the same SD as at baseline. When no SDs were available, we used the weighted average from all the other RCTs measuring the outcome with the same instrument. When studies reported medians and IQRs, we converted to means and SDs. ${ }^{20}$

We performed meta-analyses, and present results for patient-reported continuous outcomes in two ways. First, we transformed all scores to the scale of an index instrument, the highest in the hierarchy and pooled results of all studies using the mean difference as the summary measure. This resulted in scores that could range from 0 to 100 , in which higher scores signified better outcomes (less pain, better function, better QoL). Second, we used the MID of each of the instruments to determine the proportion of patients who reached a change in the outcome that was larger than a MID. To inform this analysis, a parallel team performed a linked systematic review to establish the most credible MIDs for each of the instruments used to measure pain, function and QoL. The most credible MID was the median of all the credible MIDs. Details of this review are available in a publication related to this BMJ Rapid Recommendation. (Devji T, et al. Submitted for publication 2016) We then estimated and pooled the difference in the proportion of patients between groups achieving this difference. ${ }^{16}$
When no credible MID was found for a particular instrument, we used the MID of the index instrument. Data for time-to-knee replacement was not available, so we summarised the data for knee replacement using the proportion of patients who had the outcome per group and pooled those data using relative risk as the summary measure. These meta-analyses were performed using random effects models using the Hartung-Knapp-Sidik-Jonkman method. ${ }^{21}{ }^{22}$ All analyses were performed using an intention-to-treat approach. When authors did not report data in a way that allowed incorporation it in the meta-analyses, we summarised the results narratively.

For complications, we used the number of patients having the event and the total number of patients undergoing knee arthroscopy, and pooled these data using a generalised linear mixed-effects model that allowed inclusion of studies with no events without a continuity correction. ${ }^{23}$

We planned to perform four subgroup analyses for the outcomes pain and function: trials in which there was $>50 \%$ of patients with radiographic osteoarthritis (defined as Kellgren-Lawrence grades 2-4) versus trials with $\leq 50 \%$ of patients with radiographic osteoarthritis; trials in which patients were blinded versus not blinded; trials in which meniscectomy was performed versus those in which it was not; and trials in which a control group received an active intervention (eg, exercise therapy, injections) versus control groups without such interventions (eg, waiting list, no treatment). We performed sensitivity analyses for calculating the difference in patients who achieve a change higher than the MID in two ways: (1) using the lowest and highest value of the MID of each instrument, based on the range of the MIDs that were deemed credible, and (2) calculating the standardised mean difference and then transforming the standardised mean difference into a risk difference $^{17}$ (this method does not use an MID). All data analyses used the package meta in the software R, V.3.3.1. (R: a language and environment for statistical computing (program). Vienna, Austria: $\mathrm{R}$ Foundation for Statistical Computing, 2016).

\section{Certainty of the evidence assessments}

We assessed the certainty of the estimates of effect (quality of evidence) using the Grading of Recommendations Assessment, Development and Evaluation (GRADE) approach. ${ }^{24}$ We considered potential limitations in risk of bias, inconsistency, imprecision, indirectness and publication bias. ${ }^{25-28}$ We used a modification of the Cochrane Risk of bias tool ${ }^{29}$ to assess the risk of bias of the studies informing on the effects of arthroscopic surgery, and the relevant items of the Methodological Index for Non-Randomised Studies (MINORS) tool $^{30}$ to assess the risk of bias of the studies informing on the complications of knee arthroscopy. All authors, in consultation with the parallel BMJ Rapid Recommendation guideline panel ${ }^{31}$ participated in, and 
came to consensus regarding, certainty of estimates ratings.

The median of the change in score in the control arm from the studies that reported this information and did not use sham surgery as a control provided estimates of expected outcome in the control group (which is the equivalent of the baseline risk in dichotomous outcomes), which informed calculation of absolute estimates of effect. Summary of findings tables ${ }^{32}$ created using MAGICapp ${ }^{33}$ summarised key information for all patient-important outcomes.

\section{RESULTS}

Of 710 unique references screened in title and abstract, 149 articles underwent full text screening, of which 13 RCTs informing the effects of knee arthroscopy ${ }^{13} 34-46$ and 15 studies informing the complications of knee arthroscopy (12 OS $^{47-58}$ and three RCTs ${ }^{13} 3843$ ) proved eligible (figure 1).

\section{Effects}

\section{Study characteristics}

The 13 eligible RCTs were published between 1993 and 2016, recruited a median of 119 patients, and enrolled patients with mean age from $48.9^{44}$ to $62.8^{34}$ years old and a sex distribution from $5 \%{ }^{40}$ to $81.7 \%{ }^{42}$ women. Two studies performed sham surgery in the control group ${ }^{40}{ }^{43}$ while most of the other studies used exercise therapy. ${ }^{13} 35363839414446$ table 1 presents details of study characteristics.

Figure 1 Study selection process. RCT, randomised clinical trial.

\section{Effects of knee arthroscopy}

Table 2 presents the GRADE summary of findings for effects of knee arthroscopy compared with control. Patients who underwent arthroscopic surgery had a change in pain scores larger on average than patients who received control, in the short-term ( 5.4 points on a 100-point scale, $95 \%$ CI 2.0 to $8.8, \mathrm{n}=10$ studies, 1231 patients, see online supplementary appendix figure S1) and long-term (3.1 95\% CI -0.2 to $6.4, \mathrm{n}=8$ studies, 1097 patients, see online supplementary appendix figure S2). The MID for this outcome measured with the index instrument (KOOS pain subscale) was 12 points. ${ }^{59}$ Using the MIDs specific to each instrument, (Devji T, et al. Submitted for publication 2016) 12.4\% more patients receiving arthroscopy achieved an improvement in pain greater than the MID $(n=11$ studies, 1102 patients) in the short term.

Over the first 3 months of follow-up, the median average of improvement in pain was 15 points in patients who received conservative management versus 20 points in patients who underwent knee arthroscopy; over the long term, the median average improvement 19 points in patients who received conservative management versus 22 points in patients who underwent knee arthroscopy.

Patients who underwent arthroscopic surgery had an improvement in function score that was, on average, 4.9 points larger on a 100-point scale than patients who received control in the short term (95\% CI 1.5 to 8.4, $\mathrm{n}=7$ studies, 964 patients, see online supplementary appendix figure S3), and 3.2 points larger (95\% CI -0.5

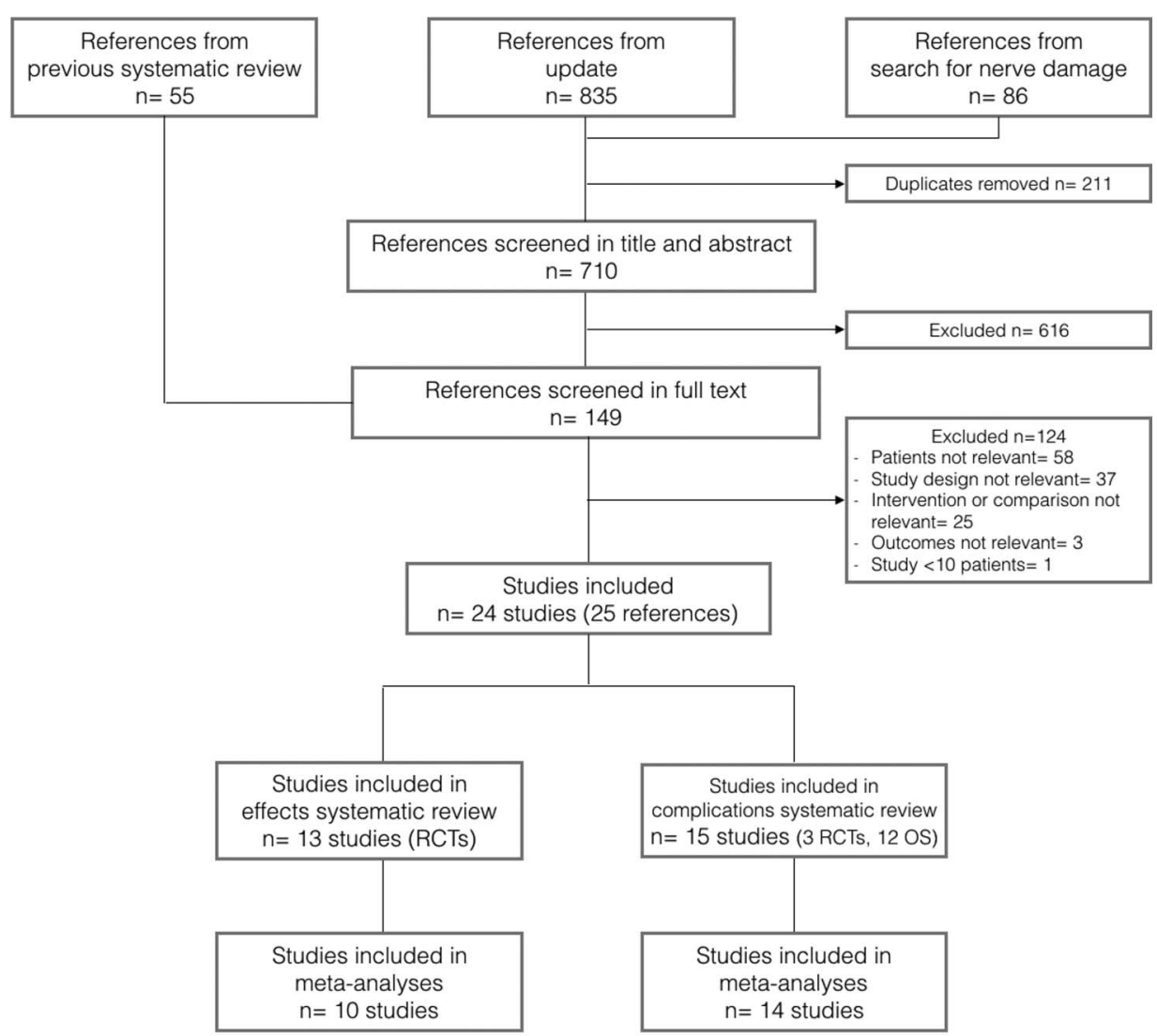


Table 1 Characteristics of randomised clinical trials included in systematic review of effects

\begin{tabular}{|c|c|c|c|c|c|c|c|c|c|c|c|}
\hline Study & $\begin{array}{l}\text { Number of } \\
\text { patients } \\
\text { enrolled }\end{array}$ & Comparator & $\begin{array}{l}\text { Patients } \\
\text { age } \\
\text { (mean) }\end{array}$ & $\begin{array}{l}\% \\
\text { females }\end{array}$ & $\begin{array}{l}\text { ROA } \\
>50 \% *\end{array}$ & $\begin{array}{l}\text { Pain } \\
\text { measure }\end{array}$ & $\begin{array}{l}\text { Baseline mean } \\
\text { intervention } \\
\text { (SD) }\end{array}$ & $\begin{array}{l}\text { Baseline } \\
\text { mean } \\
\text { control } \\
\text { (SD) }\end{array}$ & $\begin{array}{l}\text { Function } \\
\text { measure }\end{array}$ & $\begin{array}{l}\text { Baseline } \\
\text { mean (SD) }\end{array}$ & $\begin{array}{l}\text { Baseline } \\
\text { mean } \\
\text { control } \\
\text { (SD) }\end{array}$ \\
\hline Chang, $1993^{34}$ & 34 & $\begin{array}{l}\text { Close needle } \\
\text { joint lavage }\end{array}$ & 62.8 & 71.6 & $\mathrm{Y}$ & AIMS pain & $65(20)$ & $61(21)$ & $\begin{array}{l}\text { AIMS } \\
\text { physical } \\
\text { function }\end{array}$ & $23(16)$ & $17(10)$ \\
\hline Gauffin, $2014^{35}$ & 150 & $\begin{array}{l}\text { Exercise } \\
\text { therapy }\end{array}$ & 54.5 & 27.3 & $\mathrm{~N}$ & KOOS pain & $55(18)$ & $58(18)$ & KOOS ADL & $65(18)$ & $68(22)$ \\
\hline $\begin{array}{l}\text { Herrlin, 2007, } \\
2013^{37}\end{array}$ & 96 & $\begin{array}{l}\text { Exercise } \\
\text { therapy }\end{array}$ & 54 & 38.9 & $\mathrm{~N}$ & KOOS pain & $56(18)$ & $63(21)$ & KOOS ADL & $68(21)$ & $73(20)$ \\
\hline Katz, $2013^{38}$ & 351 & $\begin{array}{l}\text { Exercise } \\
\text { therapy }\end{array}$ & 58.4 & 56.7 & $\mathrm{Y}$ & KOOS pain & $54(16)$ & $53(16)$ & $\begin{array}{l}\text { WOMAC } \\
\text { function }\end{array}$ & $37(18)$ & $38(18)$ \\
\hline Kirkley, $2008^{39}$ & 188 & $\begin{array}{l}\text { Exercise } \\
\text { therapy }\end{array}$ & 59.6 & 62.9 & $\mathrm{Y}$ & $\begin{array}{l}\text { WOMAC } \\
\text { pain }\end{array}$ & $52(21)$ & $43(24)$ & $\begin{array}{l}\text { WOMAC } \\
\text { function }\end{array}$ & $51(21)$ & $43(23)$ \\
\hline Kise, $2016^{13}$ & 140 & $\begin{array}{l}\text { Exercise } \\
\text { therapy }\end{array}$ & 49.6 & 39 & $\mathrm{Y}$ & KOOS pain & $68(15)$ & $63(21)$ & KOOS ADL & $80(16)$ & $75(22)$ \\
\hline Moseley, $2002^{40}$ & 119 & Sham surgery & 52.8 & 5 & $\mathrm{Y}$ & $\begin{array}{l}\text { SF-36 } \\
\text { body pain }\end{array}$ & 39 (19) & $38(18)$ & $\begin{array}{l}\text { SF-36 } \\
\text { physical } \\
\text { function }\end{array}$ & $42(22)$ & $47(23)$ \\
\hline Osteras, $2012^{41}$ & 17 & $\begin{array}{l}\text { Exercise } \\
\text { therapy }\end{array}$ & 49.7 & 23.6 & $\mathrm{~N}$ & VAS & $37(10)$ & $35(17)$ & NM & - & - \\
\hline Saeed, $2015^{42}$ & 120 & $\begin{array}{l}\text { Hyaluronic } \\
\text { acid injection }\end{array}$ & NR & 81.7 & NR & $\begin{array}{l}\text { Knee } \\
\text { society } \\
\text { scoref }\end{array}$ & NR & NR & $\begin{array}{l}\text { Knee } \\
\text { society } \\
\text { score } \ddagger\end{array}$ & NR & NR \\
\hline Sihvonen, $2013^{43}$ & 146 & Sham surgery & 52 & 39 & $\mathrm{~N}$ & VAS & $58(20)$ & $61(20)$ & $\begin{array}{l}\text { Lysholm } \\
\text { knee } \\
\text { scoreł }\end{array}$ & NA & NA \\
\hline Stensrud, $2015^{44}$ & 82 & $\begin{array}{l}\text { Exercise } \\
\text { therapy }\end{array}$ & 48.9 & 35.4 & $\mathrm{~N}$ & $\begin{array}{l}\text { Ordinal } \\
\text { scale }\end{array}$ & NR & NR & $\begin{array}{l}\text { Ordinal } \\
\text { scale }\end{array}$ & NR & NR \\
\hline $\begin{array}{l}\text { Vermesan, } \\
2013^{45}\end{array}$ & 114 & $\begin{array}{l}\text { Steroid } \\
\text { injection }\end{array}$ & 58.4 & 79.2 & NR & $\begin{array}{l}\text { Oxford } \\
\text { knee } \\
\text { score }\end{array}$ & NR & NR & $\begin{array}{l}\text { Oxford } \\
\text { knee } \\
\text { score } \ddagger\end{array}$ & NR & NR \\
\hline Yim, $2013^{46}$ & 108 & $\begin{array}{l}\text { Exercise } \\
\text { therapy }\end{array}$ & 56.8 & 79.4 & $\mathrm{~N}$ & VAS & $52(18)$ & $49(15)$ & $\begin{array}{l}\text { Lysholm } \\
\text { score } \neq\end{array}$ & NA & NA \\
\hline
\end{tabular}

*Based on Kellgren-Lawrence classification. Grades 2-4 were considered radiographic OA

†All measures were converted to $0-100$ scale. Higher scores mean less pain and better function.

IInstrument combines pain and function together.

ADL, Function in Daily Living; AIMS, Arthritis Impact Measurement Scale; KOOS, Knee injury and Osteoarthritis Outcome Score; NA, not applicable; NM, not measured; NR, not reported;

ROA, Radiographic osteoarthritis; SF-36, 36-Item Short-Form Survey; VAS, Visual Analogue Scale; WOMAC, Western Ontario and McMaster Universities Arthritis Index. 
to $6.8, \mathrm{n}=6$ studies, 843 patients see online supplementary appendix figure S4) in the long term. The MID for this outcome measured with the index instrument (KOOS ADL subscale) was 8 points. ${ }^{59}$ The probability of achieving a change in function higher than the MID was $13.4 \%$ higher in patients receiving arthroscopy ( $\mathrm{n}=6$ studies, 835 patients) in the short term.

In the short term, patients who received conservative management achieved a median average improvement in function of 9 points, versus 14 points in patients who underwent knee arthroscopy; over the long term, the median average improvement was 10 points in patients who received conservative management versus 13 points in patients who underwent knee arthroscopy.

We were able to perform subgroup analyses according to blinding of patients and proportion of patients with radiographic osteoarthritis $>50 \%$ for both of these outcomes. None of the analyses showed differences in results between groups (see online supplementary appendix figures S5-12). All RCTs performed partial meniscectomy as part of the intervention when needed, and all used active comparators. Therefore, we did not perform subgroup analyses for these variables.

Sensitivity analyses showed that for short-term pain and short-term function, results using the upper and lower limit of the MID estimate, and the approach using the standardised mean difference, in all cases yielded lower estimates of the numbers with important benefit from arthroscopy than did our primary analysis (see online supplementary appendix 2).

Changes in QoL scores were similar between patients undergoing knee arthroscopy and patients receiving control. In the short term, the difference in change from baseline scores was 6 points greater for knee arthroscopy (95\% CI -1.5 to $13.5, n=1$ study, 120 patients). In the long term, the difference in change from baseline was 2.1 points ( $95 \% \mathrm{CI}-1.0$ to $5.2, \mathrm{n}=2$ studies, 269 patients, see online supplementary appendix figure S13). The MID for the index instrument (EQ-5D) is 15 points. ${ }^{60}$ The median average of improvement in QoL was 8 points in patients who received conservative management versus 14 points in patients who underwent knee arthroscopy in the short term; and 10.3 points in patients who received conservative management versus 12.4 points in patients who underwent knee arthroscopy.

The risk of undergoing knee replacement up to 1 year after the intervention was 1.89 times higher in patients undergoing knee arthroscopy (95\% CI 0.51 to $7, n=2$ studies, 497 patients, see online supplementary appendix figure S14).

\section{Certainty of the evidence}

There was high certainty in the estimates of effects for the outcome pain and moderate certainty in the estimates of effect for the outcome function. Although risk of bias due to lack of blinding that could affect the patient-reported outcomes was a concern in most of the trials, and the proportion of losses to follow-up was higher than desirable (see online supplementary appendix figure S15), for pain, trials with a low risk of bias reported similar results to those in which there were risk of bias concerns (see online supplementary appendix figures S5 and 7). For function, there was less evidence from trials at low risk of bias, so we rated down our certainty in evidence for risk of bias (see online supplementary appendix figures S9 and 11). In addition, the estimates for this outcome were imprecise. There was no evidence of publication bias (see online supplementary appendix figure S16).

The certainty of the estimates of QoL was low in the short term due to risk of bias and imprecision, but high in the long term. The certainty of the estimates for knee replacement was moderate due to imprecision. Table 2 presents the details of the assessments per outcome.

\section{Complications}

\section{Study characteristics}

The studies included in the complications systematic review reported data from a median of 20770 patients. Average patient age ranged from $42^{52}$ to $62.4^{56}$ years, and the proportion of women from $39 \%^{13}$ to $64.6 \% .^{49}$ table 3 presents detailed study characteristics.

\section{Complications of knee arthroscopy}

Table 4 provides a GRADE summary of findings for the complications of knee arthroscopy. Patients who underwent knee arthroscopy have an extremely small risk of death, that is, $(<1$ in $1000,95 \%$ CI 0 to $1, n=7$ studies, 454086 patients, see online supplementary appendix figure S17); a risk of VTE of five in 1000 (95\% CI 2 to $10, \mathrm{n}=11$ studies, 1119920 patients, see online supplementary appendix figure S18); a risk of infection of 2 in 1000 (95\% CI 1 to $4, n=5$ studies, 603838 patients, see online supplementary appendix figure S19) and an extremely small risk of nerve damage $(<1$ in $1000,95 \%$ CI 0 to $1, \mathrm{n}=1$ study, 12426 patients).

\section{Certainty of the evidence}

The estimates of complications of knee arthroscopy had low certainty. All studies suffered from risk of bias concerns, mainly due to the retrospective nature of the data collection (using data that had not been collected for the purposes of the study) (see online supplementary appendix figure S20). The studies informing mortality, VTE and infection showed inconsistent results from a clinical and statistical perspective, which resulted in rating down the certainty for the pooled estimate. Finally, the only study informing nerve damage included patients with arthroscopy of the shoulder as well, ${ }^{57}$ and therefore warranted rating down this estimate for indirectness. There was no evidence of publication bias (see online supplementary appendix figure S21). Table 4 presents details regarding the assessments of the certainty of the complications of knee arthroscopy per outcome. 
Table 2 Summary of findings for the effects of knee arthroscopy versus control in patients with degenerative knee disease

\begin{tabular}{|c|c|c|c|c|c|}
\hline \multirow{2}{*}{$\begin{array}{l}\text { Outcome } \\
\text { Timeframe }\end{array}$} & \multirow[b]{2}{*}{ Study results and measurements } & \multicolumn{2}{|l|}{ Absolute effect estimates } & \multirow{2}{*}{$\begin{array}{l}\text { Certainty in effect } \\
\text { estimates } \\
\text { (Quality of evidence) }\end{array}$} & \multirow[b]{2}{*}{ Summary } \\
\hline & & Conservative management & Arthroscopy & & \\
\hline \multicolumn{6}{|l|}{ Short term } \\
\hline $\begin{array}{l}\text { Pain (difference in } \\
\text { change from baseline) } \\
3 \text { months }\end{array}$ & $\begin{array}{l}\text { Measured by: different instruments } \\
\text { converted to scale of index instrument } \\
\text { (KOOS pain subscale) }\end{array}$ & $\begin{array}{l}15.0 \\
\text { Points (mean) }\end{array}$ & $\begin{array}{l}20.0 \\
\text { Points } \\
\text { (mean) }\end{array}$ & High & $\begin{array}{l}\text { On average, knee arthroscopy results } \\
\text { in very small extra reduction in pain } \\
\text { scores when compared with control }\end{array}$ \\
\hline & $\begin{array}{l}\text { Scale: } 0-100 \text { high better, minimally } \\
\text { important difference } 12 \text { ) } \\
\text { Data from } 1231 \text { patients in } 10 \text { studies } \\
\text { Follow-up } 3 \text { months }\end{array}$ & \multicolumn{2}{|c|}{$\begin{array}{l}\text { Difference: mean difference } 5.4 \text { more } \\
\text { ( } 95 \% \text { Cl } 1.9 \text { more- } 8.8 \text { more) }\end{array}$} & & \\
\hline $\begin{array}{l}\text { Pain (difference in } \\
\text { patients who achieve a } \\
\text { change higher than the } \\
\text { MID) } \\
3 \text { months }\end{array}$ & $\begin{array}{l}\text { Data from } 1102 \text { patients in } 9 \text { studies } \\
\text { Follow-up } 3 \text { months }\end{array}$ & $\begin{array}{l}669 \\
\text { Per } 1000 \\
\text { Difference: } 124 \text { more per } 1000\end{array}$ & $\begin{array}{l}793 \\
\text { Per } 1000\end{array}$ & High & $\begin{array}{l}\text { Knee arthroscopy increases the } \\
\text { number of patients with an important } \\
\text { reduction in short-term pain by } \sim 12 \text { in } \\
100\end{array}$ \\
\hline $\begin{array}{l}\text { Function (difference in } \\
\text { change from baseline) } \\
3 \text { months }\end{array}$ & $\begin{array}{l}\text { Measured by: different instruments } \\
\text { converted to scale of index instrument } \\
\text { (KOOS ADL subscale, Scale: } 0-100, \\
\text { high better } \\
\text { minimally important difference 8) } \\
\text { Based on data from } 964 \text { patients in } 7 \\
\text { studies } \\
\text { Follow-up } 3 \text { months }\end{array}$ & \multicolumn{2}{|c|}{$\begin{array}{l}\text { Difference: mean difference } 4.9 \text { more } \\
\text { ( } 95 \% \mathrm{Cl} 1.5 \text { more }-8.4 \text { more) }\end{array}$} & $\begin{array}{l}\text { Moderate } \\
\text { Owing to serious risk of bias, } \\
\text { borderline inconsistency and } \\
\text { borderline imprecision }\end{array}$ & $\begin{array}{l}\text { Knee arthroscopy may increase } \\
\text { function change slightly more than } \\
\text { control }\end{array}$ \\
\hline $\begin{array}{l}\text { Function (difference in } \\
\text { patients who achieve a } \\
\text { change higher than the } \\
\text { MID) } \\
3 \text { months }\end{array}$ & $\begin{array}{l}\text { Based on data from } 835 \text { patients in } 6 \\
\text { studies } \\
\text { Follow-up } 3 \text { months }\end{array}$ & $\begin{array}{l}519 \\
\text { Per } 1000 \\
\text { Difference: } 134 \text { more per } 1000\end{array}$ & $\begin{array}{l}653 \\
\text { Per } 1000\end{array}$ & $\begin{array}{l}\text { Moderate } \\
\text { Owing to serious risk of bias }\end{array}$ & $\begin{array}{l}\text { Knee arthroscopy probably increases } \\
\text { the number of patients with an } \\
\text { important improvement in short-term } \\
\text { function } \sim 13 \text { in } 100\end{array}$ \\
\hline $\begin{array}{l}\text { Quality of life (difference } \\
\text { in change from } \\
\text { baseline) }\end{array}$ & $\begin{array}{l}\text { Measured by: EQ-5D VAS } \\
\text { Scale: } 0-100 \text {, high better minimally } \\
\text { important difference } 15\end{array}$ & $\begin{array}{l}8.0 \\
\text { Points (mean) }\end{array}$ & $\begin{array}{l}14.0 \\
\text { Points } \\
\text { (mean) }\end{array}$ & $\begin{array}{l}\text { Low } \\
\text { Owing to serious risk of bias, } \\
\text { owing to serious imprecision }\end{array}$ & $\begin{array}{l}\text { Knee arthroscopy may have, on } \\
\text { average, little or no difference on QoL } \\
\text { change, compared with control }\end{array}$ \\
\hline 3 months & $\begin{array}{l}\text { Based on data from } 120 \text { patients in one } \\
\text { study } \\
\text { Follow-up } 3 \text { months }\end{array}$ & \multicolumn{2}{|c|}{$\begin{array}{l}\text { Difference: mean difference } 6.0 \text { greater } \\
(95 \% \mathrm{Cl} 1.5 \text { fewer-13.5 more) }\end{array}$} & & \\
\hline $\begin{array}{l}\text { Pain and function } \\
\text { up to } 3 \text { months }\end{array}$ & $\begin{array}{l}\text { Based on data from } 316 \text { patients in } 3 \\
\text { studies } \\
\text { Follow-up up to } 3 \text { months }\end{array}$ & \multicolumn{2}{|c|}{$\begin{array}{l}\text { Three studies evaluated the effects of knee } \\
\text { arthroscopy in pain and function using } \\
\text { measures that combined these two outcomes } \\
\text { together or that could not be pooled. One } \\
\text { study reported a difference in change from } \\
\text { baseline in the Oxford knee score that } \\
\text { favoured arthroscopy by } 4.9 \text { points }(95 \% \mathrm{Cl} \\
3.61 \text { to } 6.20,114 \text { patients) over steroids } \\
\text { injections. A second study reported no } \\
\text { differences in the median in an overall } \\
\text { self-assessment based on a } 7 \text {-point ordinal }\end{array}$} & $\begin{array}{l}\text { Moderate } \\
\text { Owing to serious risk of bias }\end{array}$ & $\begin{array}{l}\text { Knee arthroscopy probably has little or } \\
\text { no difference in pain and function } \\
\text { when compared with control }\end{array}$ \\
\hline
\end{tabular}

Timefram

in 10 studies

Follow-up 3 months

Data from 1102 patients in 9 studies

Per 1000

793

MID)

months

change from baseline)

Based on data from 835 patients in 6

studies

Per 1000

653 


\begin{tabular}{|c|c|c|c|c|c|}
\hline \multirow{2}{*}{$\begin{array}{l}\text { Outcome } \\
\text { Timeframe }\end{array}$} & \multirow[b]{2}{*}{ Study results and measurements } & \multicolumn{2}{|l|}{ Absolute effect estimates } & \multirow{2}{*}{$\begin{array}{l}\text { Certainty in effect } \\
\text { estimates } \\
\text { (Quality of evidence) }\end{array}$} & \multirow[b]{2}{*}{ Summary } \\
\hline & & Conservative management & Arthroscopy & & \\
\hline & & \multicolumn{2}{|c|}{$\begin{array}{l}\text { scale (82 patients) when comparing knee } \\
\text { arthroscopy to exercise therapy. The third } \\
\text { study reported that patients who received } \\
\text { intra-articular hyaluronic acid injections } \\
\text { reported less pain than patients who received } \\
\text { knee arthroscopy ( } 120 \text { patients) }\end{array}$} & & \\
\hline \multicolumn{6}{|c|}{ 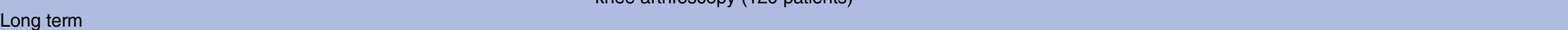 } \\
\hline $\begin{array}{l}\text { Pain (difference in } \\
\text { change from baseline) } \\
1-2 \text { years }\end{array}$ & $\begin{array}{l}\text { Measured by: different instruments } \\
\text { converted to scale of index instrument } \\
\text { (KOOS pain subscale minimally } \\
\text { important difference 12) } \\
\text { Scale: } 0-100 \text {, high better } \\
\text { Based on data from } 1097 \text { patients in } 8 \\
\text { studies } \\
\text { Follow-up } 2 \text { years }\end{array}$ & $\begin{array}{l}19.0 \\
\text { Points (mean) } \\
\text { Difference: mean difference } 3 \\
\text { (95\% Cl } 0.17 \text { fewer-6.43 mo }\end{array}$ & $\begin{array}{l}22.0 \\
\text { Points } \\
\text { (mean) } \\
3 \text { more }\end{array}$ & High & $\begin{array}{l}\text { On average, knee arthroscopy results } \\
\text { in no difference or a very small } \\
\text { reduction, in pain }\end{array}$ \\
\hline $\begin{array}{l}\text { Function (difference in } \\
\text { change from baseline) } \\
1-2 \text { years }\end{array}$ & $\begin{array}{l}\text { Measured by: different instruments } \\
\text { converted to scale of index instrument } \\
\text { (KOOS ADL subscale minimally } \\
\text { important difference } 8 \text { ) } \\
\text { Scale: } 0-100 \text {, high better } \\
\text { Based on data from } 843 \text { patients in } 6 \\
\text { studies } \\
\text { Follow-up } 2 \text { years }\end{array}$ & $\begin{array}{l}10.0 \\
\text { Points (mean) } \\
\text { Difference: mean difference } 3 \\
\text { (95\% Cl } 0.48 \text { less-6.8 more) }\end{array}$ & $\begin{array}{l}13.0 \\
\text { Points } \\
\text { (mean) } \\
\text { more }\end{array}$ & $\begin{array}{l}\text { Moderate } \\
\text { Owing to serious risk of bias } \\
\text { and borderline imprecision }\end{array}$ & $\begin{array}{l}\text { On average, knee arthroscopy } \\
\text { probably does results in no } \\
\text { improvement or a very small } \\
\text { improvement, in function }\end{array}$ \\
\hline $\begin{array}{l}\text { Quality of life (difference } \\
\text { in change from } \\
\text { baseline) }\end{array}$ & $\begin{array}{l}\text { Measured by: EQ-5D VAS, 15D } \\
\text { (converted to EQ-5D scale, MID 15) } \\
\text { Scale: } 0-100, \text { high better }\end{array}$ & $\begin{array}{l}10.3 \\
\text { Points (mean) }\end{array}$ & $\begin{array}{l}12.4 \\
\text { Points } \\
\text { (mean) }\end{array}$ & High & $\begin{array}{l}\text { On average, knee arthroscopy does } \\
\text { not result in an important improvement } \\
\text { in quality of life }\end{array}$ \\
\hline $1-2$ years & $\begin{array}{l}\text { Based on data from } 269 \text { patients in } 2 \\
\text { studies } \\
\text { Follow-up } 1 \text { year }\end{array}$ & $\begin{array}{l}\text { Difference: mean difference } 2 \\
\text { (95\% Cl } 0.96 \text { fewer-5.21 mo }\end{array}$ & 2 more & & \\
\hline $\begin{array}{l}\text { Knee replacement } \\
1-2 \text { years }\end{array}$ & $\begin{array}{l}\text { Relative risk: } 1.89 \\
(95 \% \mathrm{Cl} 0.51 \text { to } 7.0) \\
\text { Based on data from } 497 \text { patients in } 2 \\
\text { studies } \\
\text { Follow-up } 1 \text { year }\end{array}$ & $\begin{array}{l}12 \\
\text { Per } 1000 \\
\text { Difference: } 11 \text { more per } 1000 \\
\text { (95\% Cl } 107 \text { more }-6 \text { fewer) }\end{array}$ & $\begin{array}{l}23 \\
\text { Per } 1000\end{array}$ & $\begin{array}{l}\text { Moderate } \\
\text { Owing to serious imprecision }\end{array}$ & $\begin{array}{l}\text { On average, knee arthroscopy does } \\
\text { not result in an increase in the risk of } \\
\text { knee replacement }\end{array}$ \\
\hline $\begin{array}{l}\text { Pain and function } \\
1-2 \text { years }\end{array}$ & $\begin{array}{l}\text { Based on data from } 114 \text { patients in one } \\
\text { study } \\
\text { Follow-up } 1 \text { year }\end{array}$ & $\begin{array}{l}\text { One study measured pain anc } \\
\text { a composite score. The study } \\
\text { patients who receive arthrosc } \\
\text { change in Oxford knee score } \\
\text { than patients receiving steroid } \\
\text { (95\% Cl } 1.14 \text { to } 4.06)\end{array}$ & $\begin{array}{l}\text { unction using } \\
\text { lowed that } \\
\text { y have a } \\
\text { o points higher } \\
\text { injections }\end{array}$ & $\begin{array}{l}\text { Moderate } \\
\text { Owing to serious risk of bias }\end{array}$ & $\begin{array}{l}\text { Knee arthroscopy probably has little or } \\
\text { no difference on pain and function }\end{array}$ \\
\hline
\end{tabular}


Table 3 Characteristics of studies included in systematic review of complications

\begin{tabular}{|c|c|c|c|c|}
\hline Study & Design & Number of patients & Age (mean) & $\%$ females \\
\hline Basques, $2015^{47}$ & Retrospective cohort (registry) & 17774 & 53 & 46.9 \\
\hline Bohensky, $2014^{48}$ & Retrospective cohort (registry) & 139031 & NR & 42.5 \\
\hline Cancienne, $2016^{49}$ & Prospective cohort & 173216 & NR & 64.6 \\
\hline Hame, $2012^{50}$ & Retrospective cohort (registry) & 314578 & NR & 62 \\
\hline Hetsroni, $2011^{51}$ & Retrospective cohort (registry) & 418323 & 45.5 & 46.8 \\
\hline Hoppener, $2006^{52}$ & Retrospective cohort (registry) & 335 & 42 & 43.3 \\
\hline Jameson, $2011^{53}$ & Retrospective cohort (registry) & 261446 & 46 & 40.7 \\
\hline Katz, $2013^{38}$ & $\mathrm{RCT}$ & 174 & 59 & 55.9 \\
\hline Kise, $2016^{13}$ & RCT & 70 & 48.9 & 39 \\
\hline Krych, $2015^{54}$ & Retrospective cohort (registry) & 12595 & NR & NR \\
\hline Maletis, $2012^{55}$ & Retrospective cohort (registry) & 20770 & 44 & 42.8 \\
\hline Sihvonen, $2013^{43}$ & $\mathrm{RCT}$ & 70 & 52 & 58 \\
\hline Wai, $2002^{56}$ & Retrospective cohort (registry) & 14391 & 62.4 & 49.9 \\
\hline Yacub, $2009^{57}$ & Retrospective cohort (registry) & 12426 & NR & 57.3 \\
\hline Yeranosian, $2013^{58}$ & Retrospective cohort (registry) & 432038 & NR & NR \\
\hline
\end{tabular}

Table 4 Summary of findings for the complications of knee arthroscopy versus control in patients with degenerative knee disease

\begin{tabular}{|c|c|c|c|c|c|}
\hline \multirow[b]{2}{*}{$\begin{array}{l}\text { Outcome } \\
\text { Timeframe }\end{array}$} & \multirow[b]{2}{*}{$\begin{array}{l}\text { Study results and } \\
\text { measurements }\end{array}$} & \multicolumn{2}{|c|}{ Absolute effect estimates } & \multirow{2}{*}{$\begin{array}{l}\text { Certainty in effect } \\
\text { estimates } \\
\text { (Quality of } \\
\text { evidence) }\end{array}$} & \multirow[b]{2}{*}{ Summary } \\
\hline & & $\begin{array}{l}\text { Conservative } \\
\text { management }\end{array}$ & Arthroscopy & & \\
\hline $\begin{array}{l}\text { Mortality } \\
3 \text { months }\end{array}$ & $\begin{array}{l}\text { Based on data from } \\
454086 \text { patients in } 7 \\
\text { studies } \\
\text { Follow-up } 3 \text { months }\end{array}$ & $\begin{array}{l}0 \\
\text { Per } 1000 \\
\text { Difference: }<1 \mathrm{~m} \\
\text { (95\% Cl } 0 \text { more }\end{array}$ & $\begin{array}{l}0 \\
\text { Per } 1000 \\
\text { re per } 1000 \\
-1 \text { more) }\end{array}$ & $\begin{array}{l}\text { Low } \\
\text { Owing to serious } \\
\text { risk of bias and } \\
\text { serious } \\
\text { inconsistency }\end{array}$ & $\begin{array}{l}\text { Arthroscopy may have } \\
\text { an extremely small risk } \\
\text { of mortality }\end{array}$ \\
\hline $\begin{array}{l}\text { Venous } \\
\text { thromboembolism } \\
3 \text { months }\end{array}$ & $\begin{array}{l}\text { Based on data from } \\
1119920 \text { patients in } \\
11 \text { studies } \\
\text { Follow-up } 3 \text { months }\end{array}$ & $\begin{array}{l}0 \\
\text { per } 1000 \\
\text { Difference: } 5 \mathrm{mc} \\
(95 \% \mathrm{Cl} 2 \text { more }\end{array}$ & $\begin{array}{l}5 \\
\text { per } 1000 \\
\text { per } 1000 \\
-10 \text { more) }\end{array}$ & $\begin{array}{l}\text { Low } \\
\text { Owing to serious } \\
\text { risk of bias, owing } \\
\text { to serious } \\
\text { inconsistency }\end{array}$ & $\begin{array}{l}\text { Arthroscopy may have a } \\
\text { small risk for venous } \\
\text { thromboembolism }\end{array}$ \\
\hline $\begin{array}{l}\text { Infection } \\
3 \text { months }\end{array}$ & $\begin{array}{l}\text { Based on data from } \\
603838 \text { patients in } 5 \\
\text { studies } \\
\text { Follow-up } 3 \text { months }\end{array}$ & $\begin{array}{l}0 \\
\text { per } 1000 \\
\text { Difference: } 2 \text { mo } \\
\text { (95\% Cl } 1 \text { more }\end{array}$ & $\begin{array}{l}2 \\
\text { per } 1000 \\
\text { e per } 1000 \\
-4 \text { more) }\end{array}$ & $\begin{array}{l}\text { Low } \\
\text { Owing to serious } \\
\text { risk of bias, owing } \\
\text { to serious } \\
\text { inconsistency }\end{array}$ & $\begin{array}{l}\text { Arthroscopy may have a } \\
\text { very small risk for } \\
\text { infection }\end{array}$ \\
\hline $\begin{array}{l}\text { Nerve damage } \\
3 \text { months }\end{array}$ & $\begin{array}{l}\text { Based on data from } \\
12426 \text { patients in } \\
\text { one study } \\
\text { Follow-up } 3 \text { months }\end{array}$ & $\begin{array}{l}0 \\
\text { Per } 1000 \\
\text { Difference: }<1 \mathrm{~m} \\
(95 \% \mathrm{Cl} 0 \text { more }\end{array}$ & $\begin{array}{l}0 \\
\text { Per } 1000 \\
\text { re per } 1000 \\
-1 \text { more) }\end{array}$ & $\begin{array}{l}\text { Low } \\
\text { Owing to serious } \\
\text { risk of bias, owing } \\
\text { to serious } \\
\text { indirectness }\end{array}$ & $\begin{array}{l}\text { Arthroscopy may have } \\
\text { an extremely small risk } \\
\text { of nerve damage }\end{array}$ \\
\hline
\end{tabular}

\section{DISCUSSION}

This systematic review provides high-quality evidence that patients with degenerative knee disease who undergo arthroscopy experience, on average, very small benefits in pain, function and QoL over periods of up to 3 months when compared with patients who receive a conservative management strategy (table 2). Results up to 2 years failed to show benefits in pain or function, and excluded any but very small benefits (table 2). The median of the average pain change in patients receiving conservative management was 15 points in the short term and 19 points in the long term (MID 12 points). Patients receiving arthroscopy had average change 5.4 points higher in the short term, and 3.1 points higher in the long term. These differences were not patient important. Thus, whether patients receive arthroscopy or not, the clinical trial experience suggests, on average, a small benefit in pain reduction over the short and long term. 
The results for function proved similar, with very small average differences in the short term, and no convincing evidence of benefit in the long term (table 2). Patients who received a conservative management strategy had a median average change of 9 points in the short term and 10 points in the long term. (MID 8 points). Risk of bias limitations leave this evidence less secure (moderate quality) than for pain.

Study results provide high-quality evidence that the benefits of arthroscopic surgery on QoL over the long term are minimal, if they exist at all (table 2). Low-quality evidence raises the possibility of a higher risk of knee replacement with arthroscopic surgery.

We found a low risk of serious adverse effects in patients undergoing knee arthroscopy. The risk of mortality and nerve damage may be close to 0 , while the risk of VTE and infection may be five and two in 1000 patients, respectively. We have low certainty in this evidence, however, because the studies included were likely to be biased and showed results that were inconsistent.

Our systematic review has particular strengths. First, it provides the most comprehensive and trustworthy body of evidence up to date, including 10 studies not included in the most recent prior review. ${ }^{15}$ While the conclusions of our systematic review may not be qualitatively different from the conclusions of previous reviews addressing the same question, we believe that all the additions in terms of studies included and methods for summarising, presenting and appraising the evidence strengthen the conclusions derived from this body of evidence considerably. Second, this systematic review was developed in parallel with a BMJ Rapid Recommendation according to predefined standards, methods and processes. ${ }^{12}$ Extensive input from content experts and patients in the guideline panel throughout the process secured appropriate selection of outcomes and analyses as well as appropriate interpretation of the results from the systematic review. The rapid recommendations published together with our linked systematic review should provide clinicians and their patients with optimal guidance in practice and will also allow other guideline organisations to reuse or adapt content to their contexts, if needed. Third, by converting all the instruments to the scale of an index instrument we do overcome the potential limitations of using the standardised mean difference (namely, the analysis depending on a similar SD across studies, and the resulting measure of effect being difficult to interpret), and provide an estimate of the proportion of patients who would achieve a minimally important change per arm, and the difference between these proportions. This allows incorporating patients' values and preferences explicitly when interpreting the results. A rigorous linked systematic review of studies addressing the issue informed our estimates of the minimally important change (Devji T, et al. Submitted for publication 2016) and our results were robust to accounting for the uncertainty in the MID, as well as to calculating the proportion who might benefit using an approach relying on the standardised mean difference. Fourth, we provide an explicit and transparent assessment of the certainty in the absolute estimates of effect, which considers limitations of the evidence with regards to risk of bias, inconsistency, imprecision, indirectness and publication bias. ${ }^{61}$

Our review is limited by suboptimal reporting in many of the original studies, requiring imputing SDs and, in a number of studies, estimating correlations between baseline and follow-up. It is possible that there is a subgroup of patients-for instance, those with locking symptomswho do achieve substantial benefit from arthroscopic knee surgery. The available studies do not, however, provide evidence of any such subgroup. The burden of proof now rests with those who claim that such a subpopulation exists, with compelling RCT evidence required to substantiate the claim.

In summary, our results provide low-quality evidence that knee arthroscopy is a safe procedure with a low risk of complications and moderate to high-quality evidence that the procedure provides very small benefits in pain and function over conservative therapy in the short term. The evidence fails to support a persistence of these benefits over the long term. Patients and their healthcare providers must trade-off the marginal short-term benefits against the burden of the surgical procedure (pain, swelling, limited mobility, restriction of activities, over a period of 2-6 weeks).

\section{Author affiliations}

${ }^{1}$ Department of Health Research Methods, Evidence, and Impact, McMaster University, Hamilton, Ontario, Canada

${ }^{2}$ Evidence-Based Dentistry Unit, Faculty of Dentistry, Universidad de Chile, Santiago, Chile

${ }^{3}$ Department of Epidemiology and Preventive Medicine, School of Public Health and Preventive Medicine, Monash University, Melbourne, Victoria, Australia

${ }^{4}$ Monash Department of Clinical Epidemiology, Cabrini Institute, Malvern, Victoria, Australia

${ }^{5}$ Department of Orthopedic Surgery and Traumatology, Joint Research, Onze Lieve Vrouwe Gasthuis (OLVG), Amsterdam, The Netherlands

${ }^{6}$ Institute for Clinical Epidemiology and Biostatistics, University Hospital Basel, Basel, Switzerland

${ }^{7}$ HIV/STI Surveillance Research Center, and WHO Collaborating Center for HIV Surveillance, Institute for Futures Studies in Health, Kerman University of Medical Sciences, Medical University Campus, Haft-Bagh Highway, Kerman, Iran

${ }^{8}$ Division of Orthopaedics, Department of Surgery, McMaster University, Hamilton, Ontario, Canada

${ }^{9}$ Department of Medicine, Innlandet Hospital Trust-Division Gjøvik, Gjøvik, Norway

${ }^{10}$ Faculty of Medicine, Institute of Health and Society, University of Oslo, Oslo, Norway

Acknowledgements We thank members of the rapid recommendations panel for critical feedback on outcome and subgroup selection, GRADE judgments and manuscript feedback, including Reed Siemieniuk (panel chair and internist), Ian A. Harris (orthopaedic surgeon), Martin Englund (epidemiologist), Casey Quinlan (patient representative), Hazel M Wilson (patient representative), Anne Lydiatt (patient representative), Lyubov Lytvyn (patient liaison expert), Nina Rydland (physiotherapist), Stijn van de Welde (physiotherapist), Thomas Agoritsas (methodologist, internist) and Annette Kristiansen (methods editor and internist). 
Contributors GHG and POV conceived the study idea. RB-P performed the literature search. SS, BS, YC, NE and RB-P performed screening, data abstraction and risk of bias assessments. RB-P performed the data analysis RB-P, RB and GHG interpreted the data analysis. RB-P and GHG interpreted the data performed certainty of evidence assessments. RB-P wrote the first draft of the manuscript. GHG, POV, RB and RP critically revised the manuscript. All authors approved the final version of the manuscript. RB-P had full access to all of the data in the study, and takes responsibility for the integrity of the data and the accuracy of the data analysis. RB-P is guarantor.

Funding This research received no specific grant from any funding agency in the public, commercial or not-for-profit sectors. RB is funded by an Australian National Health and Medical Research Council (NHMRC) Senior Principal Research Fellowship.

Competing interests All authors have completed the ICMJE uniform disclosure form at http://www.icmje.org/coi disclosure.pdf

Disclaimer All authors declare no support from any organisation for the submitted work; no financial relationships with any organisations that might have an interest in the submitted work in the previous three years; no other financial relationships that could appear to have influenced the submitted work.

Provenance and peer review Not commissioned; externally peer reviewed.

Data sharing statement Extra data are available in the publication of the BMJ Rapid Recommendation in MAGICapp.

Open Access This is an Open Access article distributed in accordance with the Creative Commons Attribution Non Commercial (CC BY-NC 4.0) license, which permits others to distribute, remix, adapt, build upon this work noncommercially, and license their derivative works on different terms, provided the original work is properly cited and the use is non-commercial. See: http:// creativecommons.org/licenses/by-nc/4.0/

\section{REFERENCES}

1. Mahir L, Belhaj K, Zahi S, et al. Impact of knee osteoarthritis on the quality of life. Ann Phys Rehabil Med 2016;59s:e159.

2. Alkan BM, Fidan F, Tosun A, et al. Quality of life and self-reported disability in patients with knee osteoarthritis. Mod Rheumatol 2014;24:166-71.

3. Lawrence RC, Felson DT, Helmick CG, et al. Estimates of the prevalence of arthritis and other rheumatic conditions in the United States. Part II. Arthritis Rheum 2008;58:26-35.

4. Cullen KA, Hall MJ, Golosinskiy A. Ambulatory surgery in the United States, 2006. Natl Health Stat Report 2009;Jan 28;(11):1-25.

5. Roos EM, Roos HP, Ryd L, et al. Substantial disability 3 months after arthroscopic partial meniscectomy: a prospective study of patient-relevant outcomes. Arthroscopy 2000;16:619-26.

6. Pihl K, Roos EM, Nissen N, et al. Over-optimistic patient expectations of recovery and leisure activities after arthroscopic meniscus surgery. Acta Orthop 2016;87:615-21.

7. Jevsevar DS, Brown GA, Jones DL, et al. The American academy of orthopaedic surgeons evidence-based guideline on: treatment of osteoarthritis of the knee, 2nd edition. J Bone Joint Surg Am 2013;95:1885-6.

8. Brown GA. AAOS clinical practice guideline: treatment of osteoarthritis of the knee: evidence-based guideline, 2nd edition. J Am Acad Orthop Surg 2013;21:577-9.

9. Krych AJ, Carey JL, Marx RG, et al. Does arthroscopic knee surgery work? Arthroscopy 2014;30:544-5.

10. Zhang W, Moskowitz RW, Nuki G, et al. OARSI recommendations for the management of hip and knee osteoarthritis, part I: critical appraisal of existing treatment guidelines and systematic review of current research evidence. Osteoarthritis Cartilage 2007;15:981-1000.

11. Vandvik PO, Otto CM, Siemieniuk RA, et al. For those with severe, symptomatic aortic stenosis is transcatheter or open surgical aortic valve replacement in those at low to intermediate risk surgical risk? A clinical practice guideline. BMJ 2016 Sep 28;354:i5085. doi: $10.1136 / \mathrm{bmj}$.i5085.

12. Siemieniuk RA, Agoritsas T, Macdonald H, et al. Introduction to BMJ Rapid Recommendations. BMJ 2016;354:i5191.

13. Kise NJ, Risberg MA, Stensrud S, et al. Exercise therapy versus arthroscopic partial meniscectomy for degenerative meniscal tear in middle aged patients: randomised controlled trial with two year follow-up. BMJ 2016;354:i3740.
14. Khan M, Evaniew N, Bedi A, et al. Arthroscopic surgery for degenerative tears of the meniscus: a systematic review and meta-analysis. CMAJ 2014;186:1057-64.

15. Thorlund JB, Juhl CB, Roos EM, et al. Arthroscopic surgery for degenerative knee: systematic review and meta-analysis of benefits and harms. BMJ 2015;350:h2747.

16. Devji T, Guyatt GH, Lytvyn L, et al. Application of minimal important differences in degenerative knee disease outcomes: a systematic review and case study to inform BMJ Rapid Recommendations. BMJ Open 2017;7:e015587.

17. Thorlund K, Walter SD, Johnston BC, et al. Pooling health-related quality of life outcomes in meta-analysis-a tutorial and review of methods for enhancing interpretability. Res Synth Methods 2011;2:188-203.

18. Juhl $\mathrm{C}$, Lund $\mathrm{H}$, Roos EM, et al. A hierarchy of patient-reported outcomes for meta-analysis of knee osteoarthritis trials: empirical evidence from a survey of high impact journals. Arthritis 2012;2012:136245

19. Tikkinen KA, Agarwal A, Craigie S, et al. Systematic reviews of observational studies of risk of thrombosis and bleeding in urological surgery (ROTBUS): introduction and methodology. Syst Rev 2014;3:150

20. Wan X, Wang W, Liu J, et al. Estimating the sample mean and standard deviation from the sample size, median, range and/or interquartile range. BMC Med Res Methodol 2014; 14:135.

21. Hartung J, Knapp G. On tests of the overall treatment effect in meta-analysis with normally distributed responses. Stat Med 2001;20:1771-82.

22. Sidik K, Jonkman JN. A simple confidence interval for meta-analysis. Stat Med 2002;21:3153-9.

23. Stijnen T, Hamza TH, Ozdemir P. Random effects meta-analysis of event outcome in the framework of the generalized linear mixed model with applications in sparse data. Stat Med 2010;29:3046-67.

24. Guyatt GH, Oxman AD, Vist GE, et al. GRADE: an emerging consensus on rating quality of evidence and strength of recommendations. BMJ 2008;336:924-6.

25. Guyatt GH, Oxman AD, Kunz R, et al. GRADE guidelines: 7. Rating the quality of evidence-inconsistency. J Clin Epidemiol 2011;64:1294-302.

26. Guyatt GH, Oxman AD, Kunz R, et al. GRADE guidelines 6. Rating the quality of evidence--imprecision. J Clin Epidemiol 2011;64:1283-93.

27. Guyatt GH, Oxman AD, Kunz R, et al. GRADE guidelines: 8. Rating the quality of evidence--indirectness. J Clin Epidemiol 2011;64:1303-10.

28. Guyatt $\mathrm{GH}$, Oxman AD, Montori $\mathrm{V}$, et al. GRADE guidelines: 5. Rating the quality of evidence--publication bias. J Clin Epidemiol 2011;64(12):1277-82

29. GH G, JW B. Modification of Cochrane Tool to assess risk of bias in randomized trials. http://distillercer.com/resources/2016

30. Slim K, Nini E, Forestier D, et al. Methodological index for non-randomized studies (minors): development and validation of a new instrument. ANZ J Surg 2003;73:712-16.

31. Siemieniuk RAC, Harris IA, Agoritsas T, et al. Arthroscopic surgery for degenerative knee arthritis and meniscal tears: a clinical practice guideline. BMJ 2017;257:j1982.

32. Guyatt G, Oxman AD, Akl EA, et al. GRADE guidelines: 1. Introduction-GRADE evidence profiles and summary of findings tables. J Clin Epidemiol 2011;64:383-94.

33. Vandvik PO, Brandt L, Alonso-Coello $\mathrm{P}$, et al. Creating clinical practice guidelines we can trust, use, and share: a new era is imminent. Chest 2013;144:381-9.

34. Chang RW, Falconer J, Stulberg SD, et al. A randomized, controlled trial of arthroscopic surgery versus closed-needle joint lavage for patients with osteoarthritis of the knee. Arthritis Rheum 1993;36:289-96.

35. Gauffin H, Tagesson S, Meunier A, et al. Knee arthroscopic surgery is beneficial to middle-aged patients with meniscal symptoms: a prospective, randomised, single-blinded study. Osteoarthritis Cartilage 2014;22:1808-16.

36. Herrlin S, Hallander M, Wange P, et al. Arthroscopic or conservative treatment of degenerative medial meniscal tears: a prospective randomised trial. Knee Surgery Sports Traumatology Arthroscopy 2007;15:393-401.

37. Herrlin SV, Wange PO, Lapidus G, et al. Is arthroscopic surgery beneficial in treating non-traumatic, degenerative medial meniscal tears? A five year follow-up. Knee Surgery Sports Traumatology Arthroscopy 2013;21:358-64. 
38. Katz JN, Brophy $\mathrm{RH}$, Chaisson $\mathrm{CE}$, et al. Surgery versus physical therapy for a meniscal tear and osteoarthritis. $N$ Engl J Med 2013;368:1675-84.

39. Kirkley A, Birmingham TB, Litchfield RB, et al. A randomized trial of arthroscopic surgery for osteoarthritis of the knee. N Engl J Med 2008;359:1097-107.

40. Moseley JB, O'Malley K, Petersen NJ, et al. A controlled trial of arthroscopic surgery for osteoarthritis of the knee. $N$ Engl J Med 2002;347:81-8.

41. Osteras $\mathrm{H}$, Osteras $\mathrm{B}$, Torstensen TA. Medical exercise therapy, and not arthroscopic surgery, resulted in decreased depression and anxiety in patients with degenerative meniscus injury. $J$ Bodyw Mov Ther 2012;16:456-63.

42. Saeed K, Khan SA, Ahmed I. Efficacy of intra articular hyaluronic acid versus arthroscopic debridement in terms of improvement in pain score in Kellgran-Lawrence Grading II \& III osteoarthritis of knee joint. Pakistan J Med Health Sci 2015;9:1011-15.

43. Sihvonen $\mathrm{R}$, Paavola M, Malmivaara A, et al. Arthroscopic partia meniscectomy versus sham surgery for a degenerative meniscal tear. N Engl J Med 2013;369:2515-24.

44. Stensrud S, Risberg MA, Roos EM. Effect of exercise therapy compared with arthroscopic surgery on knee muscle strength and functional performance in middle-aged patients with degenerative meniscus tears: a 3-mo follow-up of a randomized controlled trial. Am J Phys Med Rehabil 2015;94:460-73.

45. Vermesan D, Prejbeanu R, Laitin S, et al. Arthroscopic debridement compared to intra-articular steroids in treating degenerative medial meniscal tears. Eur Rev Med Pharmacol Sci 2013;17:3192-6.

46. Yim JH, Seon JK, Song EK, et al. A comparative study of meniscectomy and nonoperative treatment for degenerative horizontal tears of the medial meniscus. Am J Sports Med 2013;41:1565-70.

47. Basques BA, Gardner EC, Varthi AG, et al. Risk factors for short-term adverse events and readmission after arthroscopic meniscectomy: does age matter?. Am J Sports Med 2015;43:169-75.

48. Bohensky MA, Ademi Z, deSteiger R, et al. Quantifying the excess cost and resource utilisation for patients with complications associated with elective knee arthroscopy: a retrospective cohort study. Knee 2014;21:491-6.

49. Cancienne JM, Gwathmey FW, Werner BC. Intraoperative corticosteroid injection at the time of knee arthroscopy is associated with increased postoperative infection rates in a large medicare population. Arthroscopy 2016;32:90-5.

50. Hame SL, Nguyen V, Ellerman J, et al. Complications of arthroscopic meniscectomy in the older population. Am J Sports Med 2012;40:1402-5.

51. Hetsroni I, Lyman S, Do H, et al. Symptomatic pulmonary embolism after outpatient arthroscopic procedures of the knee: the incidence and risk factors in 418,323 arthroscopies. J Bone Joint Surg Br 2011;93:47-51.

52. Hoppener MR, Ettema HB, Henny CP, et al. Low incidence of deep vein thrombosis after knee arthroscopy without thromboprophylaxis: a prospective cohort study of 335 patients. Acta Orthopaedica 2006;77:767-71.

53. Jameson SS, Dowen D, James $\mathrm{P}$, et al. The burden of arthroscopy of the knee: a contemporary analysis of data from the English NHS. $J$ Bone Joint Surg Br 2011;93:1327-33.

54. Krych AJ, Sousa PL, Morgan JA, et al. Incidence and risk factor analysis of symptomatic venous thromboembolism after knee arthroscopy. Arthroscopy 2015;31:2112-18.

55. Maletis GB, Inacio MC, Reynolds S, et al. Incidence of symptomatic venous thromboembolism after elective knee arthroscopy. $J$ Bone Joint SurgAm 2012;94:714-20.

56. Wai EK, Kreder HJ, Williams Jl. Arthroscopic debridement of the knee for osteoarthritis in patients fifty years of age or older: utilization and outcomes in the Province of Ontario. J Bone Joint Surg Am 2002:84-A:17-22

57. Yacub JN, Rice JB, Dillingham TR. Nerve injury in patients after hip and knee arthroplasties and knee arthroscopy. Am J Phys Med Rehabil 2009;88:635-41; quiz 42-4, 91.

58. Yeranosian MG, Petrigliano FA, Terrell RD, et al. Incidence of postoperative infections requiring reoperation after arthroscopic knee surgery. Arthroscopy 2013;29:1355-61.

59. Mills KA, Naylor JM, Eyles JP, et al. Examining the minimal important difference of patient-reported outcome measures for individuals with knee osteoarthritis: a model using the knee injury and osteoarthritis outcome score. J Rheumatol 2016;43:395-404

60. Walters SJ, Brazier JE. Comparison of the minimally important difference for two health state utility measures: EQ-5D and SF-6D. Qual Life Res 2005;14:1523-32.

61. Balshem $\mathrm{H}$, Helfand M, Schunemann HJ, et al. GRADE guidelines: 3 . Rating the quality of evidence. J Clin Epidemiol 2011;64:401-6.

Linked articles in this BMJ Rapid Recommendations cluster

- Siemieniuk RAC, Harris IA, Agoritsas T, et al. Arthroscopic surgery for degenerative knee arthritis and meniscal tears: a clinical practice guideline. BMJ 2017;257:j1982. doi:10.1136/bmj.j1982

Summary of the results from the Rapid Recommendation process

- Brignardello-Peterson R, Guyatt GH, Schandelmaier S, et al. Knee arthroscopy versus conservative management in patients with degenerative knee disease: a systematic review. BMJ Open 2017;7:e016114. doi:10.1136/bmjopen-2017-016114

Review of all available randomised trials that assessed the benefits of knee arthroscopy compared with non-operative care and observational studies that assessed risks

- Devji T, Guyatt GH, Lytvyn L, et al. Application of minimal important differences in degenerative knee disease outcomes: a systematic review and case study to inform BMJ Rapid Recommendations. BMJ Open 2017;7:e015587. doi:10.1136/bmjopen-2016-015587 Review addressing what level of individual change on a given scale is important to patients (minimally important difference). The study informed sensitivity analyses for the review on net benefit, informed discussions on patient values and preferences, and was key to interpreting the magnitude of effect sizes and the strength of the recommendation

- MAGICapp (www.magicapp.org) Expanded version of the results with multilayered recommendations, evidence summaries, and decision aids for use on all devices 